\title{
Social Media and Political Mobilisation: An Analysis of the July 2016 Zimbabwe Shut Down
}

\section{Ngonidzashe Mutanana}

Doctor of Philosophy Student, Institute of Lifelong Learning and Development Studies, Centre for Development Studies, Chinhoyi University of Technology, ZIMBABWE

*E-mail for correspondence: ngonidzashemtnn31@gmail.com

Received: Nov 25, 2016;

Accepted: Dec 30, 2016;

Published: Jan 28, 2017

Source of Support: Nil

No Conflict of Interest: Declared

\begin{abstract}
This study sought to carry out an analysis of the effects of the social media in political mobilization. These were analyzed using the following indicators (i) the social media as a communication tool and (ii) the role of social media in political mobilization. The study was using a one-day demonstration that occurred in Zimbabwe code named \#ZimShutDown2016 as a case study. In the study, a qualitative case study research design was used. Secondary data from online newspaper reports and Social Media Networks was used to analyze the effects of the social media movement in bringing real socio-economic and political change in developing countries such as Zimbabwe. In-depth interviews with five key informants from local universities helped in the analysis and they were identified using purposive sampling technique. Findings from the study revealed that social media is an effective tool of communication among citizens. Information is exchanged minute by minute among citizens, and this encourages 'citizenry journalism.' As such, the social media has a positive impact in mobilizing the community in bringing real social, political and economic change. The study, therefore, recommends a longer survey on the challenges of the social media movement in developing countries such as Zimbabwe.
\end{abstract}

Keywords: Social Media, Political Mobilization, Political Change

\section{INTRODUCTION}

This study analyzed the \#ZimShutDown2016 shutdown which was triggered by the social media in Zimbabwe on the $6^{\text {th }}$ day of July 2016. Information cascaded down through the Facebook, Whatsapp, Twitter and YouTube and newspaper reports have claimed the success of the one-day shutdown. This study now carries an analysis of the effects of the social media in mobilizing the community towards political change using this \#ZimShutDown2016 as a case study. There are two issues under scrutiny; the social media movement and the role of social media in political mobilization. The study makes use of secondary data obtained from online news and the social media to come up with a proper position regarding the social media movement and political mobilization. Indepth interviews are also carried out with analysts from local universities to get their perceptions on the social media movement as a political mobilization tool.

\section{BACKGROUND TO THE STUDY}

The social media, from Twitter to Facebook, is globalizing

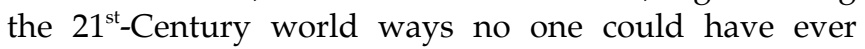
anticipated (Hershey, 2010). It is becoming a reliably chosen form of communication. Kaplain \& Haenlein (2010) in Sheedy (2011) posit that social media is a group of internet based applications that are based on ideological and technological foundations of Web 2.0. The social media allows the creation and exchange of usergenerated content. Sheedy (2011) says, "Social media are tools that are used to give people the ability to connect and unite in a crisis. They raise awareness of an issue worldwide, and usurp authoritarian governments." What it shows is that social media can be used to increase awareness among people and allows people to help each other irrespective of location.

Faris (2010) observes that the internet has an effect on authoritarian politics. He claims that social media networks can trigger informational cascades through their interaction effects with independent media outlets and on the ground organizers. What it means is that the social media is an important tool of communication to the society. Sheedy (2011) could be right when she says that the social media use can also be dangerous. Managing the public in the face of social media becomes a challenge for law enforcement agents especially in developing countries like Zimbabwe. Social media tools are used by 
individuals, but for social change to occur there must be people behind the tools (Sheedy, ibid). Some people certainly have to be on the driving wheel to ensure the success of the social change.

For Weist (2011), new communication technologies have become resources for the mobilization of collective action and the subsequent creation, organization, and implementation of social movements around the world. The main communication technology is the social media that is used via the internet. Weist (ibid) also highlights that the development of social media has fuelled cyber activism, a process of using internet based socializing and communication to create, operate and manage activism of any type. Langman (2005) also states that computer-savvy activists use the Internet to initiate and organize a broad spectrum of dissection activities and these include consumer boycotts and public protests. What it shows is that the social media is influential; it creates collectivism among community members.

The internet is used in some well-known political disturbances in the world. Cortright (2007) identifies the Iraqi anti-war movement as one where the social media played a critical role to change the situation. Activists used the internet to communicate, coordinate and create awareness among decentralized networks that resulted in global protests that brought 10 million activists together. In Egypt Weist (2011), Sheedy (2011) and Hershey (2010) state that the social media has played a role in the success of the anti-government protests that have caused the country's dictatorial leader to resign. What it shows is that social media can influence social, political or economic change.

In Zimbabwe, a shutdown was initiated on the $6^{\text {th }}$ day of July 2016 by various pressure groups involving some youngsters. A Pastor Evan Mawarire initiated the one-day demonstration through his \#FlagZimbabwe campaign alongside a Tajamuka group among some other pressure groups. The strike, code named \#ZimShutDown2016 was initiated via the Facebook, Twitter, Whatsapp, and YouTube among some other social media communications. The study, therefore, sought to analyze the effects of the social media movement in political mobilization using this \#ZimShutDown2016 as a case study.

\section{REVIEW of RELATEd Literature}

The study examines the effectiveness of social media as a tool for communication and community mobilization. If information is exchanged through the social media, the community is mobilized, and this can bring political change. Studies have shown that the social media was used for social, political and economic change in other countries like Iraqi and Egypt. Faris (2010) describes the use of social media as "revolutions without revolutionaries." The social media movement can be a tool for enacting political change in developing countries like Zimbabwe.

\section{The Social Media as a Tool for Communication}

Baruah (2012) describes social media as the use of webbased and mobile technologies to turn communication into an interactive dialogue. Faris (2010) prefer to call social media as Social Media Networks (SMNs). He posits that social media networks encompass Weblogs, social networking sites like Facebook, text messaging services, micro media services like Twitter and picture sharing services like Flickr. The social media becomes a necessary tool for communication in spite of the geographical spacing of members of a community. In Zimbabwe, Mutanana (2016) observes that the social media is becoming a reliable mode of communication. People of all ages can now communicate on issues affecting them in Zimbabwe.

Faris (2010) argues that social media networks can trigger informational cascades through their interaction effects with independent media outlets and the organizers. For instance, in Zimbabwe, there are media outlets like the Daily News, News Day, the Standard just to mention but a few that are not supportive of the current government. These independent media outlets can easily coordinate with the drivers of the social media networks cascading information. Faris (ibid) says this can be done through the reduction of costs of collective action and the transmission capabilities of certain elite nodes in social and online networks. It can also be done through changing the diffusion dynamics of informational across social networks. Information is then shared at global, regional and national level. People can also form groups at a very low cost and interaction is enabled in large numbers.

Baruah (2012) identifies some advantages of using social media as a communication tool. These include online sharing of knowledge as well as information among different groups of people. Social medial has the potential to change the character of our social lives, both on an interpersonal and community level. Faris (2010) adds; they dramatically reduce the amount of time it takes for information to travel. They increase the geographic and spatial reach of information. With the social media, people can communicate on all issues affecting them, for instance, the political and economic situation in Zimbabwe.

Castells et al (2007) have made an interesting observation about social media and power. They claim that the control of information and communication has been a source of power throughout history. Faris (2010) believes that in the political realm, information is of far-reaching importance. As such, the speed and means by which information travels is of equal importance. The social media becomes a threat to running governments, especially if they face opposition as the current Zimbabwean government. Faris (ibid) goes on; with social media networks it is difficult for regimes to cover up news stories or events. For a revolution to take place, it doesn't necessarily need revolutionaries. The social media becomes a revolutionary in itself. 


\section{Role of Social Media in Political Mobilization}

The Egyptian revolution is an example of how social media can initiate large-scale mobilization and the organization and implementation of social movements (Weist, 2011). For Faris (2010), the study of social networks is a critical variable for understanding the potential power of social media. The social media has been used for political mobilization worldwide, for instance in Egypt-Iran, Iraqi, Tunisia, Kenya just to mention but a few countries. However, the Egyptian revolution, it would seem had a large scale mobilization based on social media. Fisher (2011) states that the government banned reporters from Tahrir Square as it tried to prevent news from spreading. The social media technologies enabled protesters to become citizen journalists (Weist, 2011). This demonstrates the role of social media in political mobilization.

Weist (2011) believes that communication based on internet communication provide an additional resource for social movement implemented people who do not have resources. This offers a means for mass communication since they have financial challenges. What it shows is that Social Media Networks provide an accessible form of citizen journalism. Khamis and Vaughan (2011) define citizen journalism as the use of digital media tools to report on events on the ground. These include uploading text and videos directly to the Internet or feeding the information and videos to media outlets. Minute by minute updates happen via the social media and foreigners abroad are kept informed on developments in the country affected. In Egypt, Weist (2011) states that the social media introduced a powerful mobilization resource that protesters utilised to address the world while events were unfolding. Protesters themselves were disseminating information, pictures, videos in addition to reporters and group leaders and this was a significant development in social mobilization.

Duncombe (2010) argues that social media place the tools of documentation and truth-telling into the hands of ordinary citizens. He also adds that Social Media Networks create linked activists who can contest the narrative crafting and information controlling capabilities of authoritarian regimes. Storck (2011) observed that the implication for the role of social media is that it allows for those who are directly involved in exposing themselves to an international audience. Weist (2011) claims that Egyptian protesters were able to disseminate a continuous stream of text, videos, and images from streets of the revolution directly to millions of people via social media technologies. With social media, citizens become journalists themselves. They express their feelings, anger and even chat the way forward. Information is forwarded to news agencies, and the international community is kept informed on developments.

The major advantage of social media identified by the study is its capacity to swiftly exchange and disseminate information to millions of people inside and outside the affected country, as was the case of Egypt. The speed and interactivity of social media unite protesters and is also an outlet for seeking help when one is a danger. Weist (2011) adds; social media introduced speed and interactivity that were not possible through the reliance on traditional mobilization resources such as brochures, faxes, and telephones. Social media is a reliable tool for political mobilization. However, Storck (2011) believes successfully politically driven movements are based on the grassroots organization that are started offline and use offline tactics of an organization in conjunction with online tactics. Social Media Networks are necessary for accelerating and facilitating information.

The social media is an essential tool for communication. The society can interact at all levels; discuss socioeconomic and political issues affecting them in their daily lives. It is through this communication that the community may be mobilized to demonstrate against the government, as was the case in Egypt. No wonder Faris (2010) now believes scholars are now taking seriously claims that social media may lead to more collective action outcomes. The social media is one such tool that can be used mobilize people.

\section{Methodology}

The qualitative case study research design was used in this study. Weist (2011) describes the qualitative case study method as a useful tool for developing an understanding of a particular case. According to Stake (2005), researchers should examine both common and unique features of a case, with an emphasis on its defining features. Researchers must also acknowledge and be knowledgeable of comparable cases. Stake (ibid) claims this is necessary insofar as understanding about a particular case is related to how similar or different with others. Data collection began shortly when the study first became aware that a one day Zimbabwe shutdown was being organized by Pastor Mawarire of Zimbabwe in the month of April 2016. Data collection continued throughout until the one day shutdown; the $6^{\text {th }}$ day of July 2016. The study used a variety of sources of data originating from inside and outside Zimbabwe and these includes published newspaper reports and messages posted via social media. Such secondary data was appropriate for this study because of the nature of the inquiry and the wealth of information that was available. Given the enormous volume of data available, the study could not access every news report and social media message that was transmitted. According to Stake (2005) the qualitative researcher often must use his or her judgment which should be based on a set of criteria. This allows him/her to decide how much and how long a case should be studied to aid in understanding. Based on prior knowledge and the researcher collected a convenience sample from a large variety of sources until he reached a point of saturation and had a good sense of 
the case (Weist, 2011). Five key informants were also interviewed as an additional to support secondary data obtained. These were identified using purposive sampling and in-depth interviews as their information was valuable in so far as analyzing the effectiveness of the social media movement in enacting a real change in was concerned.

\section{DISCUSSION OF FINDINGS}

The media in Zimbabwe, from the Newsday, Daily News, The Standard, The Financial Gazette, Nehanda Radio just to mention but a few and the international media claim that all businesses were closed in Zimbabwe during the one-day stay away. There was no transport on the roads; civil servants did not report for work. Vendors could not be seen either. Only the state media, the Herald of Zimbabwe and the ZBC tried to downplay the \#ZimShutDown2016. Reporters and commentators, both social and political have attributed the success of the ZimShutDown2016 on the $6^{\text {th }}$ day of July 2016 to the social media movement which they also feel has a potential to enact real change in developing countries who are having socio-economic-political challenges such as Zimbabwe.

Key informant one (1) believes the socio-political and economic climate which is stifling Zimbabwe has triggered this social media movement. He claims the situation was compounded by economic hardships, joblessness and unpaid salaries in the month of June 2016. "As such, citizens regardless of political affiliation responded to the social media campaign and messages were transmitted through mobile applications Whatsapp to shut everything." A similar socio-political and climate have influenced the social media to ignite changes the world over. For instance in Egypt, Weist (2011) claims that under Mubarak's regime presidential and parliamentary elections were lacking transparency and corruption permeated all government bodies. The political condition for Egyptian citizens was oppressive, preventing free expression, protest opportunities, and participation. Key informant two (2) added; "there has been an outcry on the 2008 presidential and parliamentary elections and there is an outcry over corruption from different government bodies. One of the key issues that Zimbabweans seek to have addressed is many roadblocks which are hindering citizens from freedom of movement. Life is becoming difficult for the poor." Hassan (2011) also state that life was becoming difficult for the Egypt's poor to satisfy their basic needs. It was in this environment that the social media gained support in Egypt. Similarly, the social media seem to be gaining support in Zimbabwe.

The key informants have credited a Pastor Evan Mawarire for initiating the social media campaign \#ZimShutDown2016 which has attracted thousands of followers. One interviewee said; "In April 2016 he started \#ThisFlag urging Zimbabweans to mobilize to dismantle rampantly and address corruption by government ministers". Oneko (2016) adds; "a spoken word video that he posted on
Facebook in April was shared over 2000 times. This resulted in many Zimbabweans posting photos and video messages of their own about what the flag meant to them." Key informant four (4) explains the Pastor's work; "the pastor began by posting videos on social media. These videos exhibited the pastor bemoaning various socio-political and economic challenges currently affecting Zimbabweans at large". Okay Africa (2016) quotes the Pastor as saying; "we called for a complete shutdown of the country today in protest of our government that is completely failing to look after its citizenry." Now, was the social media effective in mobilizing the Zimbabwean community?

Oneko (2016) believes the social media has made it possible for news agencies to watch what is happening here in Zimbabwe through \#ZimShutDown2016. Key informant five (5) observed that the social media introduced speed and interactivity that has been lacking in the traditional mobilization techniques which are generally composed of leaflets, posters, and faxes. Key informant four (4) also notes that there were some individual activists with sufficient knowledge of social media resources who helped to bring the revolution to life. They created Facebook groups, personal blogs and Twitter accounts to engage supporters and followers. As key informant one (1) claims; protestors participated in demonstrations that led to complete closures of schools, businesses, and shops throughout Zimbabwe. Indeed, the social media has opened space where Zimbabweans can directly confront officials and disseminate information quickly. Weist (2011) claims that social media technologies represent a necessary instrumental resource that contributed to the birth and sustainability of the January 25 protests in Egypt.

In one of his articles, Magaisa (2016) states that people heeded the call for the Zimbabwe shutdown which went through the social media. He further explains that efforts by government spin doctors to downplay the mass stay away failed. Schools were not operational, and unpaid civil servants in the health and education sectors led the demonstration. Magaisa (ibid) adds; "one key factor that distinguishes the current citizen's movement from other movements in the past is the availability and use of social media." Key informant two (2) agrees with Magaisa when he says one of the key things which the social media has done is to empower Zimbabweans with information in the struggle. Magaisa (ibid) also states that citizens no longer have to wait for the media to share information because there is an upsurge in 'citizen journalism' with social media users sharing videos and uploading them by second. Khamis and Vaughan (2011) claim that citizen journalism entails using digital media tools to report on events on the ground as well as uploading text and videos directly to the Internet or feeding the information and videos to media outlets. Similarly, Zimbabweans are now able to use digital media tools to report events on the ground. 
Several news media reported the success of the event. For instance, the CNN had a headline; "a peaceful protest against corruption in Zimbabwe's leaves the streets empty." Newspapers of Zimbabwe, i.e. Newsday, Daily News, The Standard, Financial Gazette just to mention but a few had similar reports; empty streets, closed banks and businesses and Zimbabwe's cities having been not been operational. The Guardian Africa Network (2016) claims that after a mass strike in Zimbabwe, the country's 92year old president was forced to convene an emergency meeting as the nation came to a standstill. The Guardian Africa (ibid) adds; "the strike dubbed \#ZimShutDown2016 on Twitter was a rare moment of public defiance in a country that has been ruled by ZANU (PF) for more than 35 years". Okay Africa (2016) also states, "Many Zimbabwe's urban centres were not operational as citizens from a different professional backgrounds such as teachers, doctors, and nurses abandoned work." What it shows is that indeed the mass stay away was a success. The demonstration was triggered by the social media led a Pastor Mawarire. It is amazing how information was transmitted across the wider field via the Twitter, Facebook, and Whatsapp.

Magaisa (2016) also observes that even when the government sends warnings based on false and misleading technical reasoning, technical experts can challenge and reassure social media users that the government is not telling the truth. For instance, when the social media was down on the shutdown down day, Magaisa (ibid) claims that Zimbabweans around the world very quickly spread the information about how Zimbabweans could encounter this technical glitch by using VPN. Zimbabweans were provided with necessary codes and infrastructure of how to remain connected. Magaisa's finding on the dynamics of this social mobilization seem to be in agreement with Weist's (2011) finding in Egypt as he also states that what was most significant about the use of social media in the Egyptian is how it ensured social mobilization. What it shows is that the social media is dynamic in mobilizing the community.

Now, will the social media movement enact real change in Zimbabwe? Four of the informants interviewed agree with the fact that Zimbabwe is heading towards a social media movement that will enact change in Zimbabwe. Information gathered from media reports seem to be in agreement with the fact that social media can enact real change in Zimbabwe. However, the other key informant believes people are already mobilized and intimidated to follow ZANU (PF). Be that as may, the majority of Zimbabweans are now using the social the media. Mangadhla (2016) reports that according to the Postal and Telecommunications Regulatory Authority of Zimbabwe (Potraz) about 95, 6\% of subscribers in Zimbabwe rely on the internet. In the Egypt's case, Weist (2011) posits that substantial access to social media among Egyptians was available because of the government efforts to expand the nation's information technology capabilities as a tool for socioeconomic development. Similarly, in Zimbabwe the government has also made an effort to improve the information technology. With this development of an increase in the access of social media among Zimbabweans, the social media is a movement that can be used to enact real change in Zimbabwe.

\section{Conclusions}

Findings from the study have shown that the sociopolitical and economic climate which is currently stifling Zimbabwe has triggered the creation of the social media movement to try to enact real change socially, politically and economically. Findings have also revealed that this social media movement can introduce speed and interactivity that is lacking in traditional mobilization which is composed of leaflets, posters, and faxes. The social media is an effective tool of communication which has positive effects on political mobilization.

\section{RECOMMENDATIONS}

The social media has proved that it has a positive impact in some countries like Egypt and Tunisia that have realized political change as a result of the social media. The July shutdown nearly achieved its objective using the social media. Similarly, political parties are urged to take advantage of the social media ahead of the elections which are due in 2018. This study does not cover all issues to do with the social media movement; as such, it scratches the surface. The study, therefore, recommends a longer survey, in particular on the challenges of social media in political mobilization in developing countries like Zimbabwe.

\section{REFERENCES}

Baruah. D.T (2012). The effectiveness of Social Media as a Tool of Communication and its Potential for Technology Enabled Connections: A Micro-Level Study. International Journal of Scientific and Research Publications. Volume 2, Issue 5

Castells et al. (2007). Mobile Communication and Society: A Global Perspective. Cambridge. M.a: MIT Press

Duncombe. C (2010). The Twitter Revolution? Social Media Representation and Crisis in Iran and Libya. Retrieved from http:/ /law.anu.edu.au/coast/events/apsa/papers/1511.pdf

Faris. D., (2010). Revolutions Without Revolutionaries? Social Media Networks and Regime Response in Egypt. Retrieved from http:/ / repository.upenn.edu/edissertations.

Fisher.M (2011) Live Blogging Egypt: The Atlantic. Retrieved from http:/ / www.the atlantic.com/international/archive/2011/07/livebloggingegypt-day-6/70635

Guardian Africa Network (2016). \#ZimShutDown2016 and the New Protest Politics Taking Root in Zimbabwe. Retrieved from http://www.guradian.com

Hamdy.N (2009). Arab Citizen Journalism in Acton: Challenging Mainstream Media, Authorities, and Media Laws. Westminster Papers in Communication and Culture Volume 6 (1) PP 92-112

Hassan, H.A (2011). Civil Society in Egypt under Mubarak Regime. Afro Asian Journal of Social Sciences 2 (2) PP 1-18 
Hershey. M.E (2010). A Social Media Revolution: What is means for a Company's Image and the $21^{\text {st }}$ Century Job Search. Retrieved from http:/ / personal.psu.edu/jmb851/blogs

Kaplain.A.M, \& Haenlen.M. (2010). Users of the World, Unite! The Challenges and opportunities of Social Media. Business Horizons. Volume 53 PP 59-68.

Khamis.S., \& Vaugan.K (2011). Cyberactivism in Egyptian Revolution: How Civic Engagement and Citizen Journalism Tilted Balance. Arab Media and Society Volume 13

Langman. L (2005). From Virtual Public Spheres to Global Justice: A Critical Theory of Interworked Social Movements. Sociological Theory, 23 (1) PP 42-74

Magaisa. A (2016). The Big Saturday Read: Citizens Movement and the Resurgence of the Repressive State in Zimbabwe. Retrieved from http://alexmagaisa.com/big-saturday-read-citizensmovement-resurgence-repressive-state-zimbabwe.

Mangandlah. T. (2016). Zimbos in love with Whatsapp and Facebook. Retrieved from http:/ / www.theindependant.co.zw

Mutanana.N (2016). Social Networks and the Social Interaction in Family Relationships among Zimbabweans. A Survey on the Perceptions of Residents in Harare and Mashonaland West
Provinces of Zimbabwe. International Journal Research in Humanities and Social Studies. Volume 3, Issue 5

Okay Africa (2016). Here's What We Know About \#ZimShutDown2016. Retrieved from http://www.okayafrica.com/in-brief/here's-ehat-weknow-zimshutdown2016.

Sheedy.S.C,. (2011). Social Media for Social Change: A Case Study of Social Media Use in 2011 Egyptian Revolution. Capstone.

Stake, R.E. (2005). Qualitative Case Studies. In Weist.J.B. (2011). Social Media in the Egyptian Revolution: Reconsidering Resource Mobilisation Theory. International Journal of Communications Volume 5

Storck. M (2011). The Role of Social Media in Political Mobilization: A Case Study of the January 2011Egyptian Uprising. University of St Andrews. Scotland.

Weist.J.B. (2011). Social Media in the Egyptian Revolution: Reconsidering Resource Mobilisation Theory. International Journal of Communications Volume 5

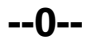

\section{Social ScIENCE RESEARCH NETWORK 2171 Monroe Avenue, Suite 203, Rochester, NY 14618, USA http://www.ssrn.com/en/} AJTP Link: http://www.ssrn.com/link/American-Journal-Trade-Policy.html 